\title{
MicroRNA biogenesis: Epigenetic modifications as another layer of complexity in the microRNA expression regulation
}

\author{
Susheel Sagar Bhat, Artur Jarmolowski and Zofia Szweykowska-Kulińska ${ }^{凶}$ \\ Department of Gene Expression, Institute of Molecular Biology and Biotechnology, Faculty of Biology, Adam Mickiewicz University, Poznań, \\ Poland
}

\begin{abstract}
Since their discovery, microRNAs have led to a huge shift in our understanding of the regulation of key biological processes. The discovery of epigenetic modifications that affect microRNA expression has added another layer of complexity to the already tightly controlled regulatory machinery. Modifications like uridylation, adenylation and RNA editing have been shown to have variable effects on miRNA biogenesis and action. Methylation of the N6 adenosine has been studied extensively in mRNA. Presence of the N6-methyl-adenosine $\left(\mathrm{m}^{6} \mathrm{~A}\right)$ mark and its critical importance in miRNA biogenesis in animals adds to our understanding of the regulatory mechanisms, while its effect on miRNA biogenesis in plants is yet to be understood.
\end{abstract}

Key words: microRNA, microRNA biogenesis, $\mathrm{m}^{6} \mathrm{~A}$ modification, $\mathrm{m}^{6} \mathrm{~A}$ RNA methyltransferase

Received: 09 June, 2016; revised: 30 June, 2016; accepted: 28 July, 2016; available on-line: 22 November, 2016

\section{INTRODUCTION}

The discovery of small non-coding RNAs and their subsequent characterisation as keysequence specific regulators of a variety of eukaryotic processes has led to the addition of another dimension in our understanding of gene regulation. Micro-RNAs (miRNAs) are a major part of the group of such small non-coding RNAs which includes a variety of other regulatory RNAs, like small interfering RNAs (siRNA), PIWI interacting RNAs (piRNA) etc. MiRNAs are $\sim 21$ nt long RNA molecules that specifically repress their target mRNAs. They were first discovered in Caenorhabditis elegans and were identified as key regulators of genes that are responsible for various developmental events (Lee et al., 1993; Wightman et al., 1993; Reinhart et al., 2000). Although since then over-expression or under-expression of miRNAs has been associated with a number of diseases (Li et al., 2012), the mechanisms regulating miRNA expression, including their biogenesis and mode of action, are still not fully understood.

\section{MicroRNA BIOGENESIS}

Although the major function of miRNAs in animals and plants is similar, the biological pathway of their biogenesis varies considerably. The differences are visible beginning with the structure and location of the miRNA genes (MIR genes). Animal miRNAs are mainly located within the introns of protein coding or non-coding RNA genes $(80 \%)$ (Kim et al., 2009). As opposed to animals, in plants most of the miRNA genes are exonic and are transcribed by independent transcription units (roughly 90\%) (Szarzynska et al., 2009; Kruszka et al., 2013; Szweykowska-Kulinska et al., 2013; Alaba et al., 2015). These genes vary vastly in length and may contain introns. Studies in humans and Arabidopsis thaliana show that splicing and complex alternative splicing events play a significant role in proper regulation of miRNA biogenesis (Laubinger et al., 2008; Bielewicz et al., 2013; Schwab et al., 2013; Agranat-Tamir et al. 2014; Mattioli et al., 2014). In both, animals and plants, the MIR genes have been shown to be clustered together, although the animal miRNA genes display considerably higher clustering (Merchan et al., 2009; Axtell et al., 2011).

\section{Animal miRNA biogenesis}

In animals, most of the miRNAs are products of the RNA polymerase II transcription, but some human miRNAs have been shown to be products of the RNA polymerase III activity (Borchert et al., 2006). Animal pri-miRNAs, bearing miRNA/miRNA* in the hairpin structure, are further processed in a two-stepreaction that is completed in the nucleus and the cytoplasm, and involves two different types of the RNase III enzymes. The initial cleavage, resulting in the formation of pre-miRNA molecules, is completed in the nucleus by DROSHA RNase III accompanied by DGCR8 and other proteins that together form a Microprocessor complex. Pre-miRNAs that already contain the mature ends of miRNA/miRNA* duplex at the opposite end of the hairpin loop structure, are then exported to the cytoplasm by Exportin 5. In the cytoplasm, another RNase III enzyme called DICER cleaves the pre-miRNA to release the miRNA/miRNA* duplex (Lee et al., 2003; Yi et al., 2003; Denli et al., 2004).

\section{Plant miRNA biogenesis}

In plants, RNA polymerase II is involved in production of the primary miRNA (pri-miRNA). These pri-miRNAs vary in length and contain a hair-pin loop structure, housing the miRNA/miRNA* duplex (Xie et al., 2005). Pri-miRNAmolecules are substrates for an RNase III type enzyme, DICER Like 1 (DCL1). DCL1, accompanied by a HYPONASTIC LEAVES 1 (HYL1), SERRATE (SE) and other proteins form the plant Microprocessor, which cleaves the pri-miRNA molecules in two steps. The first step leads to the formation of an in-

e-mail: zofszwey@amu.edu.pl

Abbreviations: DGCR8, DiGeorge Syndrome Critical Region 8; HYL1, HYPONASTIC LEAVES 1; SE, SERRATE; DCL1, DICER Like 1; RISC, RNA Induced Silencing Complex; METTL3, Methyltransferase Like 3; HNRNPA2B1, Heterogeneous Nuclear Ribonucleoprotein A2/B1 
termediary pre-miRNA, and finally the miRNA/miRNA* duplex is released. In contrast to the animal miRNA biogenesis, the initial DCL1-promoted pri-miRNA cleavage does not generate the mature ends of miRNA/miRNA* duplex at the opposite end of the pre-miRNA hairpin loop structure. Unlike in animals, all of these events take place in the nucleus in specialised sub-nuclear regions called the D-bodies, and the DCL1 RNase is the only RNase involved in generation of the miRNA/miRNA* duplexes. The miRNA/miRNA* duplex is then exported from the nucleus by the plant homolog of Exportin-5 called HASTY (Vazquez et al., 2004; Park et al., 2005; Kurihara et al., 2006; Fang \& Spector, 2007).

These miRNA/miRNA*duplexes, both in plants and animals, are then loaded onto the AGO proteins to form an RNA Induced Silencing Complex (RISC) where they selectively regulate the protein expression by either translational inhibition or mRNA degradation (Vaucheret et al., 2004; Baumberger \& Baulcombe, 2005; Qi et al., 2005; Treiber et al., 2012).

Many other proteins that are required for the biogenesis of miRNAss have been identified. These proteins are rather specific for animals or plants (for review see: Chen, 2005; Kim, 2005; Winter et al., 2009; Voinnet, 2009; Krol et al., 2010; Ha \& Kim, 2014).

\section{miRNAs TARGET GENE INTERACTION AND REGULATION}

Two major mechanisms of gene regulation via miRNAs are known, and these mechanisms depend on the degree of complementarity between the miRNA and the target mRNA. A high degree of complementarity between the miRNA and its target mRNA results in mRNA cleavage by the RISC complex. A lower degree of self-complementarity leads to regulation via translational inhibition (Zeng, 2003; Meltzer, 2005). As miRNAs can regulate targets with low self-complementarity, one miRNA can regulate more than one target and vice versa (Meltzer, 2005).

\section{In animals}

Animal miRNA binding sites in 3'UTRs are the most common, although miRNA binding sites have been shown to be present in 5'UTRs and the coding regions as well (Lewis et al, 2003; Lytle et al, 2007; Tay et al., 2008; Carthew \& Sontheimer, 2009; Schnall-Levin et al, 2010). Often, animal miRNA molecules are not highly complementary to their target $\mathrm{mRNA}$ and the prevalent gene regulation mechanism is translational inhibition. Translational inhibition can occur at the translation initiation stage (by inhibition of ribosomal assembly) or post initiation stage (by early dissociation of the ribosome assembly) (Eulalio et al, 2008; Filipowicz et al, 2008; Chekulaeva \& Filipowicz, 2009; Huntzinger \& Izaurralde, 2011; Hussain, 2012). Although the translation inhibition mechanism is vastly prevalent in animals, it cannot be assumed to be the only one (Yekta et al, 2004; Millar \& Waterhouse, 2005). Imperfect complementarity between the miRNA and its target does not lead to direct cleavage of the target, but it can cause the target degradation indirectly via deadenylation. The RISC complex along with the poly-A binding protein are important for deadynalation of $\mathrm{mRNA}$, which is followed by mRNA decapping and degradation (Bagga et al, 2005; Eulalio et al, 2009; Hussain, 2012). In another example, mammalian miRNA196 has been shown to have perfect complementarity with its target and to directly cause the cleavage of its target mRNA (Yekta et al, 2004).

\section{In plants}

Plant miRNA target sites are found within ORF's, 5'UTRs, 3'UTRs as well as noncoding transcripts (Sunkar \& Zhu, 2004; German et al, 2008; Axtell et al, 2011). Plant miRNAs are almost perfectly complementary to their target mRNAs. The miRNA induced target mRNA cleavage has been shown in many examples. However, this process is thought to overlap with translational inhibition, as was shown in the case of APATELA2 (AP2). AP2 has one to zero mismatches with the miRNA172, and yet appears to be regulated by translational inhibition, although some slicing also takes place (Aukerman \& Sakai, 2003). This points towards a more complex mechanism of gene regulation by miRNAs where interplay of both mechanisms exists.

\section{POST-TRANSCRIPTIONAL MODIFICATIONS DURING MIRNA BIOGENESIS}

After transcription, the miRNA processing-intermediates, as well as mature miRNAs, undergo a variety of modifications. These modifications may or may not have a direct effect on the miRNA action. Some of these modifications include uridylation, adenylation, RNA editing and methylation.

\section{Uridylation and adenylation}

In animals, most of the miRNAs are not methylated. These unmethylated miRNAs are usually uridylated at the 3'end by Terminal Uridylyl Transferases (TUTase), as was shown in the case of let-7, miR-10, miR99/100, miR-196 and miR125 families of miRNAs (Yu et al., 2005; Hagan et al., 2009; Thornton, 2014). Some miRNAs can also be tailed by adenylation. In mice, miRNA 122 has been shown to be adenylated by Germ Line Dependent 2 (GLD-2) after unwinding of the miRNA duplex (Katoh et al., 2009). Uridylation has been shown to be a negative regulator of the miRNAs' activity, where mono-uridylation inhibits further processing and poly-uridylation promotes degradation; adenylation has been shown to have both, positive and negative regulatory effects (Heo et al., 2008; Katoh et al., 2009; Backes et al., 2012).

In Arabidopsis, HEN1 SUPPRESSOR1 (HESO1) has been shown to uridylate the unmethylated miRNAs. The null mutants of HESO1 have been shown to carry increased amounts of miR166/165, miR169, miR171/170 and miR172, while miR173 level was increased in the HEN1 null mutant background (Ren et al., 2012). Non template adenylation has been also detected in Populus trichocarpa miRNAs where it was shown to increase the miRNA stability. The factors responsible for adenylation are not fully understood yet (Lu et al, 2009).

\section{RNA editing $(A \rightarrow I)$}

Another type of modification called RNA editing involves modification of adenosine residue into inosine $(\mathrm{A} \rightarrow \mathrm{I})$. Adenosine Deaminase Acting on RNAs (ADAR) act on double stranded RNAs and convert adenosine into inosine. The most common target RNA molecules for such editing are those that contain repetitive elements, like $A$ lu and Lines located within introns and 3'UTRs. Nearly 20\% of human pri-miRNAs have been shown to be affected by 
Table 1. Comparison of miRNA biogenesis and post transcriptional modifications in animals vs plants

\begin{tabular}{|c|c|c|}
\hline & Animals & Plants \\
\hline MIR gene location & Introns (80\%) & Exonic (90\%) \\
\hline Transcription enzyme & RNA Pol II/III & RNA Pol II \\
\hline Processing of pri-miRNA & Two step process completed in the cytoplasm & Completed in the nucleus \\
\hline \multirow{2}{*}{ Enzymes involved in processing } & DROSHA/DGCR8 (nucleus) & \multirow{2}{*}{ Micro-processor consisting of DCL1/HYL1/SE } \\
\hline & DICER (cytoplasm) & \\
\hline 3'OH methylation & Absent & $\begin{array}{l}\text { HEN1 methylates } 3^{\prime} \mathrm{OH} \text { ends before the miRNA/ } \\
\text { miRNA*duplex is exported to the cytoplasm }\end{array}$ \\
\hline Uridylation & $\begin{array}{l}\text { More common, carried out by Terminal Uridylyl } \\
\text { Transferases (TUTases) }\end{array}$ & $\begin{array}{l}\text { Unmethylated miRNAs are uridylated by HEN1 } \\
\text { Suppressor } 1 \text { (HESO1) }\end{array}$ \\
\hline Adenylation & $\begin{array}{l}\text { Germ Line Dependent } 2 \text { (GLD2) adenylates sin- } \\
\text { gle stranded miRNA, increases }\end{array}$ & $\begin{array}{l}\text { At present the enzyme is unknown, increases } \\
\text { miRNA stability }\end{array}$ \\
\hline RNA editing $(A \rightarrow I)$ & $\begin{array}{l}\text { Adenosine Deaminase Acting on RNAs (ADAR) } \\
\text { converts } A \rightarrow I \text {; may block processing of pri-miR- } \\
\text { NA or change the target specificity of miRNA }\end{array}$ & No data available \\
\hline N6A methylation & $\begin{array}{l}\text { Methyl Transferase METTL3 methylatespri-miRNA } \\
\text { and } \mathrm{m} \text { arks it for further processing }\end{array}$ & $\begin{array}{l}\text { Methyl Transferase (MTA), effect on miRNA } \\
\text { unknown }\end{array}$ \\
\hline
\end{tabular}

$A \rightarrow$ I editing. Pri-miRNA 142 and 151 were shown to undergo this kind of editing, which blocked further processing of these pri-miRNAs and their consequent accumulation (Yang et al., 2006; Kawahara et al., 2007). The $\mathrm{A} \rightarrow \mathrm{I}$ editing has been also shown to change the target specificity of miRNA 376, where the edited miRNAs target a different set of mRNAs. In this case, the $\mathrm{A} \rightarrow \mathrm{I}$ conversion does not hamper further processing of the pri-miRNA but results in the production of mature miRNAs with an altered sequence, and thus leads to targeting of a completely different set of genes (Kawahara et al., 2007).

\section{Methylation at the $3^{\prime}$ end}

In plants, HUA Enhancer I (HEN1) methylates the 3' nucleotides at the 2'O position. This happens before the miRNA/miRNA* complex is exported out of the nucleus and prevents the non-templated 3' uridylation ( $\mathrm{Li}$ et al., 2005). Methylation by HEN1 protects miRNAs, as well as siRNAs, from the HESO-1 directed uridylation, a modification that leads to miRNA instability ( $\mathrm{Yu}$ et al., 2005; Li et al., 2005).

\section{N6 Adenosine methylation}

A more ubiquitously present modification in almost all types of RNAs is the methylation of N6-adenosine. It is the most abundant in mRNAs, where it is found in almost 3-5 sites per mRNA molecule in mammals and plants. These modifications are abundant in the 3'UTR and near the stop codons (Schibler et al., 1977; Bokar et al., 1994; Meyer et al., 2012; Bodi et al., 2012; Pan, 2013). The $\mathrm{m}^{6} \mathrm{~A}$ modification has been shown to be reversible, and numerous $\mathrm{m}^{6} \mathrm{~A}$ containing mRNAs have been mapped by transcriptome wide mapping. Human METTL3 (or MTA70) and plant mRNA adenosine methylase (MTA), homologs of yeast Inducer of Meiosis 4 (IME4), have been shown to introduce the $\mathrm{m}^{6} \mathrm{~A}$ modification at a specific sequence motif: RRACH, where $R=G / A$ and $\mathrm{H}=\mathrm{A} / \mathrm{C} / \mathrm{U}$ (Wei et al., 1976; Bokar et al., 1997; Clancy et al., 2002; Bodi et al., 2010; Jia et al., 2013). Knockout of either theMETTL3 gene in the animal cell lines or the $M T A$ gene in plants has been shown to be lethal and this may indicate a crucial regulatory role of $\mathrm{m}^{6} \mathrm{~A}$ modifications (Bokar et al., 2005; Zhong et al., 2008). The discovery of two human RNA demethylases, Fat
Mass and Obesity Associated Protein (FTO) and Alpha-Ketoglutarate-Dependent Dioxygenase homolog 5 (ALKBH5), may indicate that this modification may be under a spatial or temporal control (Jia et al., 2011; Zheng et al., 2013).FTO and ALKBH5 are homologues of the non-heme $\mathrm{Fe}(\mathrm{II}) / \alpha$-ketoglutarate $(\alpha-\mathrm{KG})$ dependent ALKB family of de-oxygenases, and are known to catalyze demethylation. These proteins are conserved in vertebrates and null mutants of FTO in mice have been shown to cause various developmental defects, including lower body weight, reduced fat mass and increased postnatal lethality. Knockout of ALKBH5 causes reduced fertility while also causing an increase in the m6A content in RNA.

MicroRNA transcripts have been also shown to carry the $\mathrm{m}^{6} \mathrm{~A}$ modifications. RNA immunoprecipitation with $\mathrm{m}^{6} \mathrm{~A}$ antibodies and the presence of the consensus RRACH sequence in pri-miRNAs provide a strong evidence of $\mathrm{m}^{6} \mathrm{~A}$ presence in the human miRNAs (Berulava et al., 2015). It was also shown that knockdown of the FTO gene resulted in altered steady state levels of miRNAs (Berulava et al., 2015). Recently, the $\mathrm{m}^{6} \mathrm{~A}$ modification was shown to act as a mark for animal pri-miRNA processing. It was shown that DGCR8 identifies the $\mathrm{m}^{6} \mathrm{~A}$ mark and then recruits DROSHA to cleave the pri-miRNA and yield pre-miRNA. The $\mathrm{m}^{6} \mathrm{~A}$ modification was shown to be enriched in the pri-miRNA regions proximal to the pre-miRNA sequences (Alarcón et al., 2015). A recent study revealed that a nuclear reader protein HNRNPA2B1 mediates recruitment of the microprocessor machinery for further processing. HNRNPA2B1 was shown to bind directly to the $\mathrm{m}^{6} \mathrm{~A}$ mark, enhancing the binding of DGCR8 to pri-miRNA transcripts and affecting the miRNA biogenesis in a manner similar to METTL3 (Alarcón, C.R. et al., 2015). Figure 2 summarizes the action of MET'TL3 in animal miRNA biogenesis.

Almost nothing is known about the influence and abundance of $\mathrm{m}^{6} \mathrm{~A}$ in the plant miRNA precursors. In Arabidopsis thaliana, the $\mathrm{m}^{6} \mathrm{~A}$ mark is abundant in mRNA and has been shown to be enriched around the start codons, as well as the 3'UTR and stop codons. Plants with reduced level of METTL3 (MTA70) display highly altered phenotypes (Bodi et al., 2012; Luo et al., 2014). A homolog of human HNRNPA2B1 is also present in 


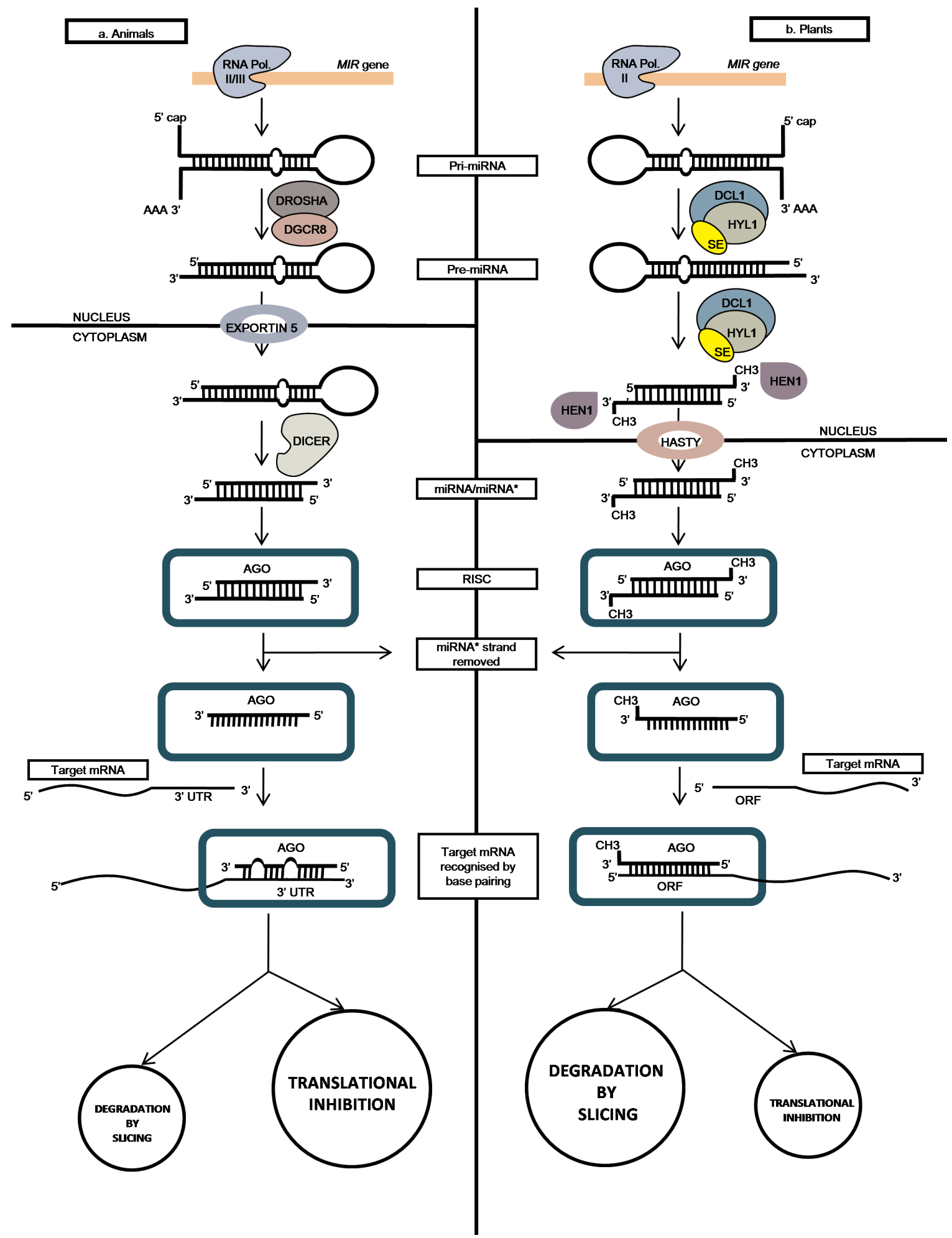

Figure 1. MicroRNA biogenesis overview:

(a) Animals: The MIR genes can be transcribed by either RNA polymerase II or III. DROSHA, together with the DGCR8 protein, cleaves the pri-miRNA to form pre-miRNA, which is exported by EXPORTIN5 to the cytoplasm, where DICER cleaves pre-miRNA to release the miRNA/miRNA* duplex. miRNA/miRNA* duplex is then incorporated into the AGO proteins, forming the RNA induced Silencing Complex. Gene expression is regulated by recognition of the target mRNA by RISC via sites present mainly in the $3^{\prime} U T R$ of mRNA. Translation inhibition is the major mechanism, while some examples of degradation by slicing have been also observed. (b) Plants: The MIR genes are transcribed by RNA polymerase II. Pri-miRNA is processed by DCL1, leading to the formation of intermediary pre-miRNA and finally miRNA/miRNA* complex. HEN1 methylatesmiRNA/miRNA* duplex at the $3^{\prime}$ ends, protecting it from HESO1 mediated uridylation. miRNA/miRNA* duplex is then exported to the cytoplasm by HASTY, where it is incorporated into AGO proteins to form the RNA induced Silencing Complex (RISC).Target sites are present within the ORFs, 5'UTRs and $3^{\prime} U T R s$. miRNAs are highly complementary to the target mRNAs, and gene expression is regulated by the mRNA degradation pathway, although translation inhibition has been also observed. 


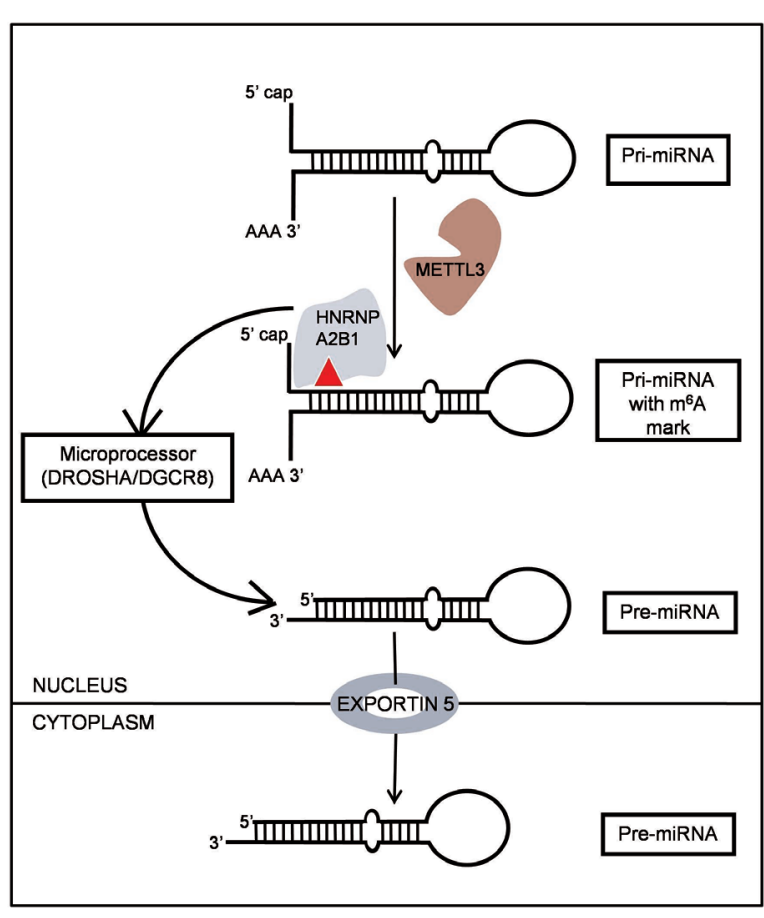

Figure 2. Role of METTL3 and HNRNPA2B1 in miRNA biogenesis in animals:

The pri-miRNA is marked by METTL3 with the $\mathrm{m}^{6} \mathrm{~A}$ mark. HNRNPA2B1 reads the $\mathrm{m}^{6} \mathrm{~A}$ mark and promotes binding of DGCR8, which helps in efficient recruitment of the Microprocessor.

Arabidopsis, but nothing is known about its role in the miRNA biogenesis.

\section{CONCLUSIONS}

The presence of $\mathrm{m}^{6} \mathrm{~A}$ in $\mathrm{mRNA}$ has been studied extensively and although the mechanism of its action is not well known, it is clear that it plays important roles in regulation of various metabolic functions. The discovery of two $\mathrm{m}^{6} \mathrm{~A}$ mRNA demethylases in humans provides us with some evidence that this modification is reversible and thus brings up many more questions regarding the dynamics of this modification. The recent discovery of $\mathrm{m}^{6} \mathrm{~A}$ as a mark for primiRNA processing adds miRNAs to the group of RNAs affected by this modification. It is imperative for us to know how big is the effect exerted by $\mathrm{m}^{6} \mathrm{~A}$ modifications on the global RNA levels, and how its absence or presence changes the dynamics of gene regulation.

With significant discoveries being made in the context of $\mathrm{m}^{6} \mathrm{~A}$ modifications in the animal miRNAs, the time is apt to know more about this modification and its implication in plants. We already know that the $\mathrm{m}^{6} \mathrm{~A}$ mark in mRNAs is critical for the proper development of plants. To know if the effect of $\mathrm{m}^{6} \mathrm{~A}$ modification extends to the miRNA level and how it regulates the plant miRNA biogenesis is an exciting new avenue in research. Does the $\mathrm{m}^{6} \mathrm{~A}$ mark work in the same way as it does in humans and marks the primiRNA for further processing, and are there any mediators like HNRNA2B1 involved? These are some of the questions that are waiting to be answered. With the interest in the $\mathrm{m}^{6} \mathrm{~A}$ mark in plant miRNA just gathering pace, we are sure to have some answers in the near future.

\section{Acknowledgements}

This work was supported by the KNOW RNA Research Centre in Poznan, 01/KNOW2/2014 and Dzialanosc Statutowa of the Faculty of Biology, AMU, Poznan.

\section{REFERENCES}

Agranat-Tamir L, Shomron N, Sperling J, Sperling R (2014) Interplay between pre-mRNA splicing and microRNA biogenesis within the supraspliceosome. Nucleic Acids Res 42: 4640-4651. http://dx.doi. org/10.1093/nar/gkt1413

Alaba S, Piszczalka P, Pietrykowska H, Pacak AM, Sierocka I, Nuc PW, Singh K, Plewka P, Sulkowska A, Jarmolowski A, Karlowski WM (2014) The liverwort Pellia endiviifolia shares microtranscriptomic traits that are common to green algae and land plants. New Phytologist 206: 352-367. http://dx.doi.org/10.1111/nph.13220

Alarcón CR, Goodarzi H, Lee H, Liu X, Tavazoie S, Tavazoie SF (2015) HNRNPA2B1 Is a mediator of m6A-dependent nuclear RNA processing events. Cell 162: 1299-1308. http://doi:10.1016/j. cell.2015.08.011

Alarcón CR, Lee H, Goodarzi H, Halberg N, Tavazoie SF (2015) N6methyladenosine marks primary microRNAs for processing. Nature 519: 482-485. http://dx.doi.org/10.1038/nature14281

Aukerman MJ, Sakai H (2003) Regulation of flowering time and floral organ identity by a microrna and its APETALA2-like target genes. The Plant Cell Online 15: 2730-2741. http://dx.doi.org/10.1105/ tpc.016238

Axtell MJ, Westholm JO, Lai EC (2011) Vive la difference: biogenesis and evolution of microRNAs in plants and animals. Genome Biology 12: 221. http://dx.doi.org/10.1186/gb-2011-12-4-221

Backes S, Shapiro JS, Sabin LR, Pham AM, Reyes I, Moss B, Cherry S (2012) Degradation of host microRNAs by poxvirus poly (A) polymerase reveals terminal RNA methylation as a protective antiviral mechanism. Cell Host \& Microbe 12: 200-210. http://dx.doi. org/10.1016/j.chom.2012.05.019

Bagga S, Bracht J, Hunter S, Massirer K, Holtz J, Eachus R, Pasquinelli AE (2005) Regulation by let-7 and lin-4 miRNAs results in target mRNA degradation. Cell 122: 553-563. http://dx.doi. org/10.1016/j.cell.2005.07.031

Baumberger N, Baulcombe DC (2005) Arabidopsis ARGONAUTE1 is an RNA Slicer that selectively recruits microRNAs and short interfering RNAs. Proc Nat Acad Sci 102: 11928-11933. http://dx.doi. org/10.1073/pnas.0505461102

Berulava T, Rahmann S, Rademacher K, Klein-Hitpass L, Horsthemke B (2015) N6-adenosine methylation in MiRNAs. PLOS ONE 10: e0118438. http://dx.doi.org/10.1371/journal.pone.0118438

Bielewicz D, Kalak M, Kalyna M, Windels D, Barta A, Vazquez F, Szweykowska-Kulinska Z, Jarmolowski A (2013) Introns of plant pri-miRNAs enhance miRNA biogenesis. EMBO Reports 14: 622628. http://dx.doi.org/10.1038/embor.2013.62

Bodi Z, Button JD, Grierson D, Fray RG (2010) Yeast targets for mRNA methylation. Nucleic Acids Res 38: 5327-5335. http://dx.doi. org/10.1093/nar/gkq266

Bodi Z, Zhong S, Mehra S, Song J, Graham N, Li H, May S, Fray RG (2012) Adenosine methylation in Arabidopsis mRNA is associated with the $3^{\prime}$ end and reduced levels cause developmental defects. Frontiers Plant Sci 3: 48. http://dx.doi.org/10.3389/ fpls.2012.00048

Bokar JA (2005) The biosynthesis and functional roles of methylated nucleosides in eukaryotic mRNA. Topics Curr Genet 141-177. http:// dx.doi.org/10.1007/b106365

Bokar JA, Rath-Shambaugh ME, Ludwiczak R, Narayan P, Rottman F (1994) Characterization and partial purification of mRNA N6-adenosine methyltransferase from HeLa cell nuclei. Internal mRNA methylation requires a multisubunit complex. J Biol Chem 1: 1769717704.

Bokar JA, Shambaugh ME, Polayes D, Matera AG, Rottman FM (1997) Purification and cDNA cloning of the AdoMet-binding subunit of the human mRNA (N6-adenosine)-methyltransferase. $R N A 3$ : 1233-1247.

Borchert GM, Lanier W, Davidson BL (2006) RNA polymerase III transcribes human microRNAs. Nature Struct Mol Biol 13: $1097-$ 1101. http://dx.doi.org/10.1038/nsmb1167

Carthew RW, Sontheimer EJ (2009) Origins and mechanisms of miRNAs and siRNAs. Cell 136: 642-655. http://dx.doi.org/10.1016/j. cell.2009.01.035

Chekulaeva M, Filipowicz W (2009) Mechanisms of miRNA-mediated post-transcriptional regulation in animal cells. Curr Opin Cell Biol 21: 452-460. http://dx.doi.org/10.1016/j.ceb.2009.04.009

Chen X (2005) MicroRNA biogenesis and function in plants. FEBS Lett 579: 5923-5931. http://dx.doi.org/10.1016/j.febslet.2005.07.071

Clancy MJ, Shambaugh ME, Timpte CS, Bokar JA (2002) Induction of sporulation in Saccharomyces cerevisiae leads to the formation of N6- 
methyladenosine in mRNA: a potential mechanism for the activity of the IME4 gene. Nucleic Acids Res 30: 4509-4518. http://dx.doi. org/10.1093/nar/gkf573

Denli AM, Tops BB, Plasterk RH, Ketting RF, Hannon GJ (2004) Processing of primary microRNAs by the Microprocessor complex. Nature 432: 231-235. http://dx.doi.org/10.1038/nature03049

Eulalio A, Huntzinger E, Izaurralde E (2008) Getting to the root of miRNA-mediated gene silencing. Cell 132: 9-14. http://dx.doi. org/10.1016/j.cell.2007.12.024

Eulalio A, Huntzinger E, Nishihara T, Rehwinkel J, Fauser M, Izaurralde $\mathrm{E}$ (2009) Deadenylation is a widespread effect of miRNA regulation. RNA 15: 21-32. http://dx.doi.org/10.1261/rna.1399509

Fang Y, Spector DL (2007) Identification of nuclear dicing bodies containing proteins for microRNA biogenesis in living Arabidopsis plants. Current Biol 17: 818-823. http://dx.doi.org/10.1016/j. cub.2007.04.005

Filipowicz W, Bhattacharyya SN, Sonenberg N (2008) Mechanisms of post-transcriptional regulation by microRNAs: are the answers in sight? Nature Rev Genet 9: 102-114. http://dx.doi.org/10.1038/ $\operatorname{nrg} 2290$

German MA, Pillay M, Jeong DH, Hetawal A, Luo S, Janardhanan P, Kannan, V, Rymarquis LA, Nobuta K, German R, De Paoli E (2008) Global identification of microRNA-target RNA pairs by parallel analysis of RNA ends. Nature Biotechnol 26: 941-946. http:// dx.doi.org/10.1038/nbt1417

Ha M, Kim VN (2014) Regulation of microRNA biogenesis. Nature Rev Mol Cell Biol 15: 509-524. http://dx.doi.org/10.1038/nrm3838

Hagan JP, Piskounova E, Gregory RI (2009) Lin28 recruits the TUTase Zcchc11 to inhibit let-7 maturation in mouse embryonic stem cells. Nature Struct Mol Biol 16: 1021-1025. http://dx.doi.org/10.1038/ nsmb.1676

Heo I, Joo C, Cho J, Ha M, Han J, Kim VN (2008) Lin28 mediates the terminal uridylation of let-7 precursor MicroRNA. Mol Cell 32: 276-284. http://dx.doi.org/10.1016/j.molcel.2008.09.014

Huntzinger E, Izaurralde E (2011) Gene silencing by microRNAs: contributions of translational repression and mRNA decay. Nature Rev Genet 12: 99-110. http://dx.doi.org/10.1038/nrg2936

Hussain MU (2012) Micro-RNAs (miRNAs): genomic organisation, biogenesis and mode of action. Cell Ttissue Res 349: 405-413. http:// dx.doi.org/10.1007/s00441-012-1438-0

Jia G, Fu Y, He C (2013) Reversible RNA adenosine methylation in biological regulation. Trends Genet 29: 108-115. http://dx.doi. org/10.1016/j.tig.2012.11.003

Jia G, Fu Y, Zhao X, Dai Q, Zheng G, Yang Y, Yi C, Lindahl T, Pan T, Yang YG, He C (2011) N6-methyladenosine in nuclear RNA is a major substrate of the obesity-associated FTO. Nature Chem Biol 7: 885-887. http://dx.doi.org/10.1038/nchembio.687

Katoh T, Sakaguchi Y, Miyauchi K, Suzuki T, Kashiwabara SI, Baba T, Suzuki T (2009) Selective stabilization of mammalian microRNAs by $3^{\prime}$ adenylation mediated by the cytoplasmic poly (A) polymerase GLD-2. Genes Develop 23: 433-438. http://dx.doi.org/10.1101/ gad.1761509

Kawahara Y, Zinshteyn B, Chendrimada TP, Shiekhattar R, Nishikura $K$ (2007) RNA editing of the microRNA-151 precursor blocks cleavage by the Dicer-TRBP complex. EMBO Rep 8: 763-769. http://dx.doi.org/10.1038/sj.embor.7401011

Kawahara Y, Zinshteyn B, Sethupathy P, Iizasa H, Hatzigeorgiou AG, Nishikura K (2007) Redirection of silencing targets by adenosine-toinosine editing of miRNAs. Science 315: 1137-1140. http://dx.doi. org/10.1126/science. 1138050

Kim VN (2005) MicroRNA biogenesis: coordinated cropping and dicing. Nature Rev Mol Cell Biol 6: 376-385. http://dx.doi.org/10.1038/ nrm1644

Kim VN, Han J, Siomi MC (2009) Biogenesis of small RNAs in animals. Nature Rev Mol Cell Biol 10: 126-139. http://dx.doi. org/10.1038/nrm2632

Krol J, Loedige I, Filipowicz W (2010) The widespread regulation of microRNA biogenesis, function and decay. Nature Rev Genet 11: 597-610. http://dx.doi.org/10.1038/nrg2843

Kruszka K, Pacak A, Swida-Barteczka A, Stefaniak AK, Kaja E, Sierocka I, Karlowski W, Jarmolowski A, Szweykowska-Kulinska Z (2013) Developmentally regulated expression and complex processing of barley pri-microRNAs. BMC Genomics 14: 34. http://dx.doi. org/10.1186/1471-2164-14-34

Kurihara Y, Takashi Y, Watanabe Y (2006) The interaction between DCL1 and HYL1 is important for efficient and precise processing of pri-miRNA in plant microRNA biogenesis. RNA 12: 206-212. http://dx.doi.org/10.1261/rna.2146906

Laubinger S, Sachsenberg T, Zeller G, Busch W, Lohmann JU, Rätsch G, Weigel D (2008) Dual roles of the nuclear cap-binding complex and SERRATE in pre-mRNA splicing and microRNA processing in Arabidopsis thaliana. Proc Natl Acade Sci 105: 8795-8800. http:// dx.doi.org/10.1073/pnas.0802493105

Lee RC, Feinbaum RL, Ambros V (1993) The C. elegans heterochronic gene lin-4 encodes small RNAs with antisense complementa- rity to lin-14. Cell 75: 843-854. http://dx.doi.org/10.1016/00928674(93)90529-y

Lee Y, Ahn C, Han J, Choi H, Kim J, Yim J, Lee J, Provost P, Rådmark O, Kim S, Kim VN (2003). The nuclear RNase III Drosha initiates microRNA processing. Nature 425: 415-419. http://dx.doi. org/10.1038/nature01957

Lewis BP, Shih IH, Jones-Rhoades MW, Bartel DP, Burge CB (2003) Prediction of mammalian microRNA targets. Cell 115: 787-798. http://dx.doi.org/10.1016/s0092-8674(03)01018-3

Li J, Yang Z, Yu B, Liu J, Chen X (2005) Methylation protects miRNAs and siRNAs from a 3'-end uridylation activity in Arabidopsis. Curr Biol 15: 1501-1507. http://dx.doi.org/10.1016/j. cub.2005.07.029

Li Y, Kowdley KV (2012) MicroRNAs in common human diseases. Genomics, Proteomics \& Bioinformatics 10: 246-253. http://dx.doi. org/10.1016/i.gpb.2012.07.005

Lu S, Sun YH, Chiang VL (2009) Adenylation of plant miRNAs. Nucleic Acids Res gkp031. http://dx.doi.org/10.1093/nar/gkp031

Luo GZ, MacQueen A, Zheng G, Duan H, Dore LC, Lu Z, Liu J, Chen K, Jia G, Bergelson J, He C (2014) Unique features of the m6A methylome in Arabidopsis thaliana. Nature Commun 5: 5630. http://dx.doi.org/10.1038/ncomms6630

Lytle JR, Yario TA, Steitz JA (2007) Target mRNAs are repressed as efficiently by microRNA-binding sites in the $5^{\prime}$ UTR as in the $3^{\prime}$ UTR. Proc Natl Acad Sci 104: 9667-9672. http://dx.doi.org/10.1073/ pnas.0703820104

Mattioli C, Pianigiani G, Pagani F (2014) Cross talk between spliceosome and microprocessor defines the fate of pre-mRNA. Wiley Interdisciplinary Rev: RNA 5: 647-658. http://dx.doi.org/10.1002/ wrna. 1236

Meltzer PS (2005) Cancer genomics: small RNAs with big impacts. $\mathrm{Na}$ ture 435: 745-746. http://dx.doi.org/10.1038/435745a

Merchan F, Boualem A, Crespi M, Frugier F (2009) Plant polycistronic precursors containing non-homologous microRNAs target transcripts encoding functionally related proteins. Genome Biol 10: R136. http://dx.doi.org/10.1186/gb-2009-10-12-r136

Meyer KD, Saletore Y, Zumbo P, Elemento O, Mason CE, Jaffrey SR (2012) Comprehensive analysis of mRNA methylation reveals enrichment in 3' UTRs and near stop codons. Cell 149: 1635-1646. http://dx.doi.org/10.1016/j.cell.2012.05.003

Millar AA, Waterhouse PM (2005) Plant and animal microRNAs: similarities and differences. Functional \& Integrative Genomics 5: 129-135. http://dx.doi.org/10.1007/s10142-005-0145-2

Pan T (2013) N6-methyl-adenosine modification in messenger and long non-coding RNA. Trends Biochem Sci 38: 204-209. http://dx.doi. org/10.1016/j.tibs.2012.12.006

Park MY, Wu G, Gonzalez-Sulser A, Vaucheret H, Poethig RS (2005) Nuclear processing and export of microRNAs in Arabidopsis. Proc Natl Acad Sci US A 102: 3691-3696. http://dx.doi.org/10.1073/ pnas.0405570102

Qi Y, Denli AM, Hannon GJ (2005) Biochemical specialization within Arabidopsis RNA silencing pathways. Mol Cell 19: 421-428. http:// dx.doi.org/10.1016/j.molcel.2005.06.014

Reinhart BJ, Slack F, Basson M, Pasquinelli A, Bettinger J, Rougvie A, Horvitz HR, Ruvkun G (2000) The 21-nucleotide let-7 RNA regulates developmental timing in Caenorbabditis elegans. Nature 403: 901-906. http://dx.doi.org/10.1038/35002607

Ren G, Chen X, Yu B (2012) Uridylation of miRNAs by hen1 suppressor1 in Arabidopsis. Curr Biol 22: 695-700. http://dx.doi. org/10.1016/j.cub.2012.02.052

Schibler U, Kelley DE, Perry RP (1977) Comparison of methylated sequences in messenger RNA and heterogeneous nuclear RNA from mouse L cells. J Mol Biol 115: 695-714. http://dx.doi. org/10.1016/0022-2836(77)90110-3

Schnall-Levin M, Zhao Y, Perrimon N, Berger B (2010) Conserved microRNA targeting in Drosophila is as widespread in coding regions as in 3' UTRs. Proc Natl Acad Sci 107: 15751-15756. http://dx.doi. org/10.1073/pnas.1006172107

Schwab R, Speth C, Laubinger S, Voinnet O (2013) Enhanced microRNA accumulation through stemloop-adjacent introns. EMBO Rep 14: 615-621. http://dx.doi.org/10.1038/embor.2013.58

Sunkar R, Zhu JK (2004) Novel and stress-regulated microRNAs and other small RNAs from Arabidopsis. The Plant Cell 16: 2001-2019. http://dx.doi.org/10.1105/tpc.104.022830

Szarzynska B, Sobkowiak L, Pant BD, Balazadeh S, Scheible WR, Mueller-Roeber B, Jarmolowski A, Szweykowska-Kulinska Z (2009) Gene structures and processing of Arabidopsis thaliana HYL1dependent pri-miRNAs. Nucleic Acids Res 37: 3083-3093. http:// dx.doi.org/10.1093/nar/gkp189

Szweykowska-Kulinska Z, Jarmolowski A, Vazquez F (2013) The crosstalk between plant microRNA biogenesis factors and the spliceosome. Plant Signaling Behavior 8: e26955. http://dx.doi.org/10.4161/ psb. 26955

Tay Y, Zhang J, Thomson AM, Lim B, Rigoutsos I (2008) MicroRNAs to Nanog, Oct4 and Sox 2 coding regions modulate embry- 
onic stem cell differentiation. Nature 455: 1124-1128. http://dx.doi. org/10.1038/nature07299

Treiber T, Treiber N, Meister G (2012) Regulation of microRNA biogenesis and function. Thrombosis Haemostasis 107: 605-610. http:// dx.doi.org/10.1160/th11-12-0836

Vaucheret H, Vazquez F, Crété P, Bartel DP (2004) The action of ARGONAUTE1 in the miRNA pathway and its regulation by the miRNA pathway are crucial for plant development. Genes Dev 1187-1197. http://dx.doi.org/10.1101/gad.1201404

Vazquez F, Gasciolli V, Crété P, Vaucheret H (2004) The nuclear dsRNA binding protein HYL1 is required for microRNA accumulation and plant development, but not posttranscriptional transgene silencing. Curr Biol 14: 346-351. http://dx.doi.org/10.1016/j. cub.2004.01.035

Voinnet O (2009) Origin, biogenesis, and activity of plant microRNAs. Cell 136: 669-687. http://dx.doi.org/10.1016/j.cell.2009.01.046

Wei CM, Gershowitz A, Moss B (1976) 5'-Terminal and internal methylated nucleotide sequences in HeLa cell mRNA. Biochemistry 15: 397-401. http://dx.doi.org/10.1021/bi00647a024

Wightman B, Ha I, Ruvkun G (1993) Posttranscriptional regulation of the heterochronic gene lin-14 by lin- 4 mediates temporal pattern formation in C. elegans. Cell 75: 855-862. http://dx.doi, org/10.1016/0092-8674(93)90530-4

Winter J, Jung S, Keller S, Gregory RI, Diederichs S (2009) Many roads to maturity: microRNA biogenesis pathways and their regulation. Nature Cell Biol 11: 228-234. http://dx.doi.org/10.1038/ ncb0309-228

Xie Z, Allen E, Fahlgren N, Calamar A, Givan SA, Carrington JC (2005) Expression of Arabidopsis MIRNA genes. Plant Physiol 138: 2145-2154. http://dx.doi.org/10.1104/pp.105.062943

Yang W, Chendrimada TP, Wang Q, Higuchi M, Seeburg PH, Shiekhattar R, Nishikura K (2006) Modulation of microRNA processing and expression through RNA editing by ADAR deaminases. Nature Struct Mol Biol 13: 13-21. http://dx.doi.org/10.1038/ nsmb1041

Yekta S, Shih IH, Bartel DP (2004) MicroRNA-directed cleavage of HOXB8 mRNA. Science 304: 594-596. http://dx.doi.org/10.1126/ science. 1097434

Yi R, QinY, Macara IG and Cullen BR (2003) Exportin-5 mediates the nuclear export of pre-microRNAs and short hairpin RNAs. Genes Dev 17: 3011-3016. http://dx.doi.org/10.1101/gad.1158803

Yu B, Yang Z, Li J, Minakhina S, Yang M, Padgett RW, Steward R, Chen X (2005) Methylation as a crucial step in plant microRNA biogenesis. Science 307: 932-935. http://dx.doi.org/10.1126/science.1107130

Zeng Y, Yi R, Cullen BR (2003) MicroRNAs and small interfering RNAs can inhibit mRNA expression by similar mechanisms. Proc Natl Acad Sci 100: 9779-9784. http://dx.doi.org/10.1073/ pnas. 1630797100

Zheng G, Dahl JA, Niu Y, Fedorcsak P, Huang CM, Li CJ, Vågbø CB, Shi Y, Wang WL, Song SH, Lu Z (2013). ALKBH5 is a mammalian RNA demethylase that impacts RNA metabolism and mouse fertility. Mol Cell 49: 18-29. http://dx.doi.org/10.1016/j.molcel.2012.10.015

Zhong S, Li H, Bodi Z, Button J, Vespa L, Herzog M, Fray RG (2008) MTA is an Arabidopsis messenger RNA adenosine methylase and interacts with a homolog of a sex-specific splicing factor. The Plant Cell 20: 1278-1288. http://dx.doi.org/10.1105/tpc.108.058883

Reinhart BJ, Slack F, Basson M, Pasquinelli A, Bettinger J, Rougvie A, Horvitz HR, Ruvkun G (2000) The 21-nucleotide let-7 RNA regulates developmental timing in Caenorbabditis elegans. Nature 403: 901-906.

Ren G, Chen X, Yu B (2012) Uridylation of miRNAs by hen1 suppressor1 in Arabidopsis. Curr Biol 22: 695-700.

Schibler U, Kelley DE, Perry RP (1977) Comparison of methylated sequences in messenger RNA and heterogeneous nuclear RNA from mouse L cells. J Mol Biol 115: 695-714.
Schnall-Levin M, Zhao Y, Perrimon N, Berger B (2010) Conserved microRNA targeting in Drosophila is as widespread in coding regions as in 3' UTRs. Proc Natl Acad Sci 107: 15751-15756.

Schwab R, Speth C, Laubinger S, Voinnet O (2013) Enhanced microRNA accumulation through stemloop-adjacent introns. EMBO Reports 14: 615-621.

Sunkar R, Zhu JK (2004) Novel and stress-regulated microRNAs and other small RNAs from Arabidopsis. The Plant Cell 16: 2001-2019.

Szarzynska B, Sobkowiak L, Pant BD, Balazadeh S, Scheible WR, Mueller-Roeber B, Jarmolowski A, Szweykowska-Kulinska Z (2009) Gene structures and processing of Arabidopsis thaliana HYL1-dependent pri-miRNAs. Nucleic Acids Res gkp189.

Szweykowska-Kulinska Z, Jarmolowski A, Vazquez F (2013) The crosstalk between plant microRNA biogenesis factors and the spliceosome. Plant Signaling Behavior 8: e26955.

Tay Y, Zhang J, Thomson AM, Lim B, Rigoutsos I (2008) MicroRNAs to Nanog, Oct4 and Sox 2 coding regions modulate embryonic stem cell differentiation. Nature 455: 1124-1128.

Treiber T, Treiber N, Meister G (2012) Regulation of microRNA biogenesis and function. Thrombosis Haemostasis 107: 605.

Vaucheret H, Vazquez F, Crété P, Bartel DP (2004) The action of ARGONAUTE1 in the miRNA pathway and its regulation by the miRNA pathway are crucial for plant development. Genes Dev 18: 1187-1197.

Vazquez F, Gasciolli V, Crété P, Vaucheret H (2004) The nuclear dsRNA binding protein HYL1 is required for microRNA accumulation and plant development, but not posttranscriptional transgene silencing. Curr Biol 14: 346-351.

Voinnet O (2009) Origin, biogenesis, and activity of plant microRNAs. Cell 136: 669-687.

Wei CM, Gershowitz A, Moss B (1976) 5'-Terminal and internal methylated nucleotide sequences in HeLa cell mRNA. Biochemistry 15: 397-401.

Wightman B, Ha I, Ruvkun G (1993) Posttranscriptional regulation of the heterochronic gene lin-14 by lin- 4 mediates temporal pattern formation in C. elegans. Cell 75: 855-862.

Winter J, Jung S, Keller S, Gregory RI, Diederichs S (2009) Many roads to maturity: microRNA biogenesis pathways and their regulation. Nature Cell Biol 11: 228-234.

Xie Z, Allen E, Fahlgren N, Calamar A, Givan SA, Carrington JC (2005) Expression of Arabidopsis MIRNA genes. Plant Physiol 138: 2145-2154.

Yang W, Chendrimada TP, Wang Q, Higuchi M, Seeburg PH, Shiekhattar R, Nishikura K (2006) Modulation of microRNA processing and expression through RNA editing by ADAR deaminases. Nature Struct Mol Biol 13: 13-21.

Yekta S, Shih IH, Bartel DP (2004) MicroRNA-directed cleavage of HOXB8 mRNA. Science 304: 594-596.

Yi R, Qin Y, Macara IG, Cullen BR (2003) Exportin-5 mediates the nuclear export of pre-microRNAs and short hairpin RNAs. Genes Dev 17: 3011-3016.

Yu B, Yang Z, Li J, Minakhina S, Yang M, Padgett RW, Steward R, Chen X (2005) Methylation as a crucial step in plant microRNA biogenesis. Science 307: 932-935.

Zeng Y, Yi R, Cullen BR (2003) MicroRNAs and small interfering RNAs can inhibit mRNA expression by similar mechanisms. Proc Natl Acad Sci 100: 9779-9784.

Zheng G, Dahl JA, Niu Y, Fedorcsak P, Huang CM, Li CJ, Vågbø CB, Shi Y, Wang WL, Song SH, Lu Z (2013) ALKBH5 is a mammalian RNA demethylase that impacts RNA metabolism and mouse fertility. Mol Cell 49: 18-29.

Zhong S, Li H, Bodi Z, Button J, Vespa L, Herzog M, Fray RG (2008) MTA is an Arabidopsis messenger RNA adenosine methylase and interacts with a homolog of a sex-specific splicing factor. The Plant Cell 20: 1278-1288. 